\title{
Platelet-derived growth factor BB stimulates differentiation of rat immature Leydig cells
}

\author{
Yiyan Wang1, Xiaoheng Li1, Fei Ge', Kaiming Yuan', Zhijian Su², Guimin Wang1, Qingquan Lian'1 and Ren-Shan Ge1 \\ 'Department of Anesthesiology, The Second Affiliated Hospital and Yuying Children's Hospital, Wenzhou Medical University, Wenzhou, \\ People's Republic of China \\ 2Institutes of Life and Health Engineering, Jinan University, Guangzhou, People's Republic of China \\ Correspondence should be addressed to R-S Ge: r_ge@yahoo.com
}

\begin{abstract}
Platelet-derived growth factor (PDGF) is one family of growth factors that regulate cell growth and differentiation. Rat Leydig cells express PDGF- $\beta$ receptor (PDGFRB) during pubertal development. However, the mechanism of PDGF in the regulation of Leydig cell development is unclear. In the present study, rat immature Leydig cells were isolated from the testes of 35-day-old Sprague-Dawley rats and treated with 1 and $10 \mathrm{ng} / \mathrm{mL}$ of PDGF-BB. After $24 \mathrm{~h}$ of treatment, these cells were harvested for genomics profiling and the medium steroids were measured. 1 and $10 \mathrm{ng} / \mathrm{mL}$ PDGF-BB significantly increased

Key Words

- Platelet-derived growth factor BB

- rat immature Leydig cells

- steroidogenic acute regulatory protein

- Fos androgen production by rat immature Leydig cells. Genomics profiling analysis showed that the expression levels of steroidogenic acute regulatory protein (Star) were increased by 2-fold. Further analysis showed that Fos expression level was increased 2- and 5 -fold by 1 and $10 \mathrm{ng} / \mathrm{mL}$ PDGF-BB, respectively. In conclusion, PDGF-BB stimulated the differentiation of rat immature Leydig cells via regulating Star.

Journal of Molecular Endocrinology (2018) 60, 29-43
\end{abstract}

\section{Introduction}

Testosterone stimulates fertility and maintains the secondary sexual characteristics of males at adulthood (Ye et al. 2017). The primary source of this hormone in males is the Leydig cell, which is located in the interstitial area of a mammalian testis. Pituitarysecreted luteinizing hormone (LH) and its receptor (LHCGR), cholesterol transportation into the Leydig cell via high-density lipoprotein receptor (SCARB1) and into the mitochondrion via steroidogenic acute regulatory protein (STAR) and androgen-biosynthetic enzymes, including P450 cholesterol side chain cleavage enzyme (CYP11A1), 3 3 -hydroxysteroid dehydrogenase 1 (HSD3B1), 17 $\alpha$-hydroxylase/17,20-lyase (CYP17A1) and 17ß-hydroxysteroid dehydrogenase 3 (HSD17B3), are very critical for the production of testosterone in Leydig cells (Ge \& Hardy 2007).
However, the development of adult Leydig cells is also very important for the formation of the male body (Ye et al. 2017). The pubertal development of Leydig cells is conceptually divided into four stages: stem, progenitor, immature and adult Leydig cells (Ye et al. 2017). In rats, Leydig cells arise from stem Leydig cells (Ge et al. 2006), which are first identified in the early postnatal (6-dayold) rat testis (Ge et al. 2006) and are shown to have the capability of self-renewing or differentiating into androgen-producing Leydig cell lineage. The first cell seen in the Leydig cell lineage is the spindle-shaped progenitor Leydig cell, which is located adjacent to the stem Leydig cells and appears in the interstitial area around pre-puberty (12 day old) (Hardy et al. 1991, Ge \& Hardy 1998, Mendis-Handagama \& Ariyaratne 2001). The progenitor Leydig cell expresses the Leydig cell lineage 
biomarker, LHCGR, SCARB1, STAR, CYP11A1, HSD3B1 and CYP17A1. The progenitor Leydig cell also has the high level of androgen-metabolizing enzyme $5 \alpha$-reductase 1 (SRD5A1, gene Srd5a1) (Ge \& Hardy 1998, Feng et al. 2016) and $3 \alpha$-hydroxysteroid dehydrogenase (AKR1C9 gene Akr1c9) (Ge \& Hardy 1998). However, the progenitor Leydig cell lacks the final-step androgen-biosynthetic enzyme (HSD17B3) for testosterone biosynthesis. Thus, the androstenedione formed after the enzyme catalysis of CYP11A1, HSD3B1 and CYP17A1 is metabolized into $5 \alpha$-androstanedione by SRD5A1 and further by AKR1C9 into androsterone, which is secreted into the circulation (Ge \& Hardy 1998). The progenitor Leydig cell has the high proliferative capacity too, amplifying the Leydig cell number (Ge \& Hardy 1997). Around puberty (age, 35 days) in the rat, the progenitor Leydig cell transits into the immature Leydig cell, which is ovoid in shape and contains abundant lipid droplets. The immature Leydig cell has well-developed androgen-biosynthetic enzymes, including HSD17B3, but also has high levels of SRD5A1 and ARK1C9, and therefore, the formation of testosterone by HSD17B3 is metabolized into dihydrotestosterone by SRD5A1 and further into androstanediol (DIOL) by AKR1C9 (Ge \& Hardy 1998). The immature Leydig cell has the intermediate proliferative capacity (Ge \& Hardy 1997) and can divide once (Hardy et al. 1989). The immature Leydig cell matures into the adult Leydig cell around adult stages (56 day old). The adult Leydig cell is round in shape and produces mainly testosterone because the androgenmetabolizing enzyme SRD5A1 in adult Leydig cells is silenced around postnatal day 56 (Ge \& Hardy 1998).

Many factors have been reported to regulate the proliferation and differentiation of Leydig cells, including LH, growth factors, cytokines and steroids (see review Chen et al. 2009, Ye et al. 2017). One family of growth factors is platelet-derived growth factors (PDGFs). PDGFs are disulfide-linked homodimeric proteins. The family of growth factors has been reported to regulate cell proliferation, tissue remodeling, differentiation and growth (Basciani et al. 2010).

Members of the PDGF family have been shown to be involved in the development of Leydig cells. PDGF-A and PDGF-B are expressed in the rat testis, forming homodimers of PDGF-AA and PDGF-BB as well as a heterodimer PDGF-AB (Betsholtz et al. 2001). In fetal, neonatal and pubertal rat testis, PDGF-A and PDGF-B were found to be present in Sertoli cells (Gnessi et al. 1995, Li et al. 1997, Uzumcu et al. 2002), and in adult rat testis, these two factors were found to be expressed in both Sertoli and Leydig cells (Gnessi et al. 1992). There are at least two PDGF receptors that respond to PDGF stimulation. The PDGF homodimers bind to their corresponding tyrosine kinase receptors, PDGF receptor $\alpha$ (PDGFRA) and PDGF receptor $\beta$ (PDGFRB), and the PDGF-AB heterodimer binds to both PDGFRA and PDGFRB, thereby activating the unique downstream pathways (Betsholtz et al. 2001).

Both PDGF-A/PDGFRA and PDGF-B/PDGFRB are essential for the development of Leydig cells (Schmahl et al. 2008). Adult Leydig cells did not differentiate in the adult knockout mice, which lacked expression of the Pdgfa (Gnessi et al. 1995). Knockout of Pdgfra gene led to few Leydig cells in fetal mouse testis (Brennan et al. 2003). Leydig cell conditional 1 knockout of Pdgfra or Pdgfrb also led to a significant reduction of Leydig cell number in the fetal testis (Schmahl et al. 2008). However, the role of PDGF-BB in the pubertal development of Leydig cells is still not clear. Our objective of the present study was to analyze the possible regulatory effects of PDGF-BB on the Leydig cell lineage. To do so, we isolated rat immature Leydig cells and treated them with PDGF-BB in vitro. We identified a series of downstreamed genes that were regulated by PDGF-BB.

\section{Materials and methods}

\section{Chemicals}

Rat PDGF-BB was purchased from R\&D Systems Inc. PDGFRB tyrosine kinase inhibitor IV (521233, also called PKI) was purchased from Calbiochem. LH (USDAbLH-B-6) was provided by USDA Animal Hormone Program (Beltsville, MD, USA). Testosterone was purchased from Steraloids Inc (Newport, RI, USA), and $\left[1,2,6,7,16,17-{ }^{3} \mathrm{H}(\mathrm{N})\right]$-testosterone was purchased from PerkinElmer. Testosterone antibody was from MP Biomedicals (Solon, OH, USA). The RatRef-12 Expression BeadChip for genome-wide expression was purchased from Illumina Inc (San Diego, CA, USA).

\section{Animals}

Sixty 28-day-old male Sprague-Dawley rats (Laboratory Animal Center, Wenzhou Medical University, Wenzhou, China) were raised in a 12-h darkness/light cycle temperature at $23 \pm 2{ }^{\circ} \mathrm{C}$, and relative humidity of $45 \%-55 \%$. Water and food were accessed ad libitum. After one-week adjustment, rats (35-day-old) were used for the isolation 
of immature Leydig cells. All studies were approved by the Wenzhou Medical University's Animal Care and Use Committee and were performed in accordance with the Guide for the Care and Use of Laboratory Animals.

\section{Leydig cell isolation}

Immature Leydig cells were purified as previously described (Ge \& Hardy 1998). Immature Leydig cells were used because they have been reported to express PDGFRB, and they have all testosterone biosynthetic and metabolizing enzymes (Ge \& Hardy 1998). In brief, the removed testis was perfused with a collagenase solution via the testicular artery and digested with the M-199 medium containing collagenase and DNase (Sigma-Aldrich) for $15 \mathrm{~min}$. Then, the suspension was filtered through $100 \mu \mathrm{m}$ 2-layer nylon mesh and the cells were separated under a Percoll gradient (Sigma-Aldrich). The cells with a density of $1.07-1.088 \mathrm{~g} / \mathrm{mL}$ were collected and washed. Purified cells were evaluated by histochemical staining for HSD3B1 activity, with $0.4 \mathrm{mM}$ etiocholanolone as the steroid substrate and $\mathrm{NAD}^{+}$as a cofactor (Payne et al. 1980). The purity of immature Leydig cells was $\geq 95 \%$.

\section{Immature Leydig cell culture}

To test the effects of PDGF-BB on androgen biosynthesis, isolated immature Leydig cells were seeded at each well of a 12-well plate. Cells were cultured in the presence of different concentrations of PDGF-BB $(0,1$ or $10 \mathrm{ng} / \mathrm{mL})$ alone or plus LH $(10 \mathrm{ng} / \mathrm{mL})$ or 22R-hydroxycholesterol (22R, $2 \mu \mathrm{M})$ in 1:1 DMEM:F-12 culture medium containing $0.1 \%$ bovine serum albumin in $5 \% \mathrm{O}_{2}$ and $34^{\circ} \mathrm{C}$ for $24 \mathrm{~h}$, and this culture system causes very low oxidative stress of Leydig cells (Weissman et al. 2005). 22R was used because immature Leydig cells are permeable to 22R, which was served as the substrate of CYP11A1 to judge its enzyme activity (Ge \& Hardy 1998). 1 or $10 \mathrm{ng} / \mathrm{mL}$ PDGF-BB were added to immature Leydig cells, and the cells were cultured for $24 \mathrm{~h}$. After that, the media were collected for analysis of androgen. In another set of experiment, PDGF-BB $(10 \mathrm{ng} / \mathrm{mL})$ and its inhibitor PKI $(20 \mathrm{nM})$ were used alone or in combination. 20 nM PKI was used because it had selective inhibition for PDGFRB $\left(\mathrm{IC}_{50}=4.2 \mathrm{nM}\right)$ over PDGFRA $\left(\mathrm{IC}_{50}=45 \mathrm{nM}\right)$ (Ho et al. 2005). Medium testosterone and androstanediol from 24-h culture media were measured, and then the levels after treatment were compared with the control (no treatment, basal).

\section{Thymidine incorporation}

Immature Leydig cells were labeled with $\left[{ }^{3} \mathrm{H}\right]$ thymidine (DuPont-New England Nuclear, Boston, MA, USA) at $1 \mathrm{Ci} / \mathrm{mL}$ (specific activity $104.7 \mathrm{Ci} / \mathrm{mmol}$ ) during the last $2 \mathrm{~h}$ of incubation as described (Ge \& Hardy 1997). After labeling, the Leydig cells were washed twice with PBS and harvested by centrifugation at $750 \mathrm{~g}$. Leydig cells were lysed in $0.5 \mathrm{~mL}$ hyamine hydroxide (ICN Radiochemicals, Irvine, CA, USA), and radioactivity was measured in a liquid scintillation counter (PerkinElmer).

\section{RNA extraction}

Total RNAs were extracted from immature Leydig cells using the TRIzol Kit according to the manufacturer's instructions (Invitrogen). Briefly, rat immature Leydig cells were collected after treatment with PDGF-BB $(0,1$ or $10 \mathrm{ng} / \mathrm{mL})$ for $24 \mathrm{~h}$ and dissolved in TRIzol and homogenized in a glass homogenizer, and total RNAs were extracted. RNA pellets were eluted with $70 \%$ ethanol and air dried. Total RNAs were resuspended in the RNasefree water and purified using the RNeasy Kit (Qiagen) according to the manufacturer's instructions. The RNA concentration was determined using a NanoDrop 2000 spectrophotometer (Thermo Fisher Scientific) and the RNA integrity in individual RNA samples were analyzed with Agilent 2100 Bioanalyzer (Santa Clara, CA, USA).

\section{Microarray hybridization and scanning}

The RatRef-12 Expression BeadChip containing 21,910 rat genes was used. Genes are picked up from the NCBI RefSeq database to cover the whole rat transcriptome. Three groups of samples were used: 0,1 , and $10 \mathrm{ng} / \mathrm{mL}$ PDGF-BB-treated immature Leydig cells. Four replicates per group were performed. Probe labeling, hybridization, washing and scanning were performed using the Illumina Total Prep Kit (Applied Biosystems) as previously described (Griffin et al. 2010). First strand of cDNA was synthesized in a total volume of $20 \mu \mathrm{L}$ with the supplied reagents. The complete first strand product was used for the second strand synthesis, followed by column purification. The purified product was then used for in vitro transcription using T7 polymerase. Biotin-16-dUTP was incorporated and the biotinylated complementary RNA (cRNA) probe as prepared. The probe integrity was verified using the Agilent 2100 Bioanalyzer. Labeled cRNA (750 ng) was hybridized to the array chip overnight at $58^{\circ} \mathrm{C}$ in a total volume of $30 \mu \mathrm{L}$ of hybridization buffer, followed by 
post-hybridization stringency washing. The chip was scanned in the NextSeq 550 System (Illumina).

\section{Microarray data analysis}

Microarray data analysis was performed as previously described (Wang et al. 2016). Briefly, after scanning, the microarray data were imported into the BeadStudio software (Illumina) for normalization, preliminary analysis and filtering. The background subtraction was performed, and the Illumina custom error model was used to generate present/absent calls for each probe ('present' defined as $P<0.01$ for signal detection) and to call differentially expressed genes (defined as $P<0.05$ after false discovery rate correction). For each array, all probe sets were normalized to a mean signal intensity value of 100. Normalized data from BeadStudio was filtered to exclude genes not expressed in the Leydig cells (i.e. data from probes that were classed as 'absent' in all samples). All of the 21,910 genes were present in the data based on which further analyses were carried out. The data were further imported into Microsoft Access 2010, and queries to find the increased and decreased genes after PDGF-BB treatment when compared to the control were generated to find the expression levels.

\section{Biological pathway analysis}

Biological pathway analysis was performed as previously described (Wang et al. 2016). The Gene MicroArray Pathway Profiler 2.1 (GenMAPP2.1, San Francisco, CA, USA) software was used to find the biological pathway, and GO pathway was generated according to the software developer's instruction. The GenMAPP2.1 was used to create a map of signal pathways for the potential pathways. We imported our statistical results into the program and illustrated biological pathways containing differentially expressed genes. The results of the differential gene expression profile were validated by RT-qPCR.

\section{Quantitative real-time PCR (RT-qPCR)}

Briefly, first-strand synthesis of DNA and RT-qPCR were performed as previously described (Lin et al. 2009). RT-qPCR was carried out in a $20 \mu \mathrm{L}$ volume in a 96-well plate using the SYBR Green PCR Kit from Applied Biosystems. Primer titration was performed with the concentration of $300 \mathrm{nM}$. Fluorescence was detected using the ABI 7700 system (PE Applied Biosystems). Each sample was run in duplicate and in parallel with no template controls. The relative mRNA levels of targeted genes were adjusted to house-keeping gene, ribosomal protein S16 (Rps16), as the internal control. Rsp16 in Leydig cells has been used as the internal control in many studies because it showed consistent expression (Ge et al. 2005, Zhang et al. 2015). Furthermore, in this microarray, the values for Rsp16 levels in 0, 1 and $10 \mathrm{ng} / \mathrm{mL}$ PDGF-BB groups were $40 \pm 3,50 \pm 6$, and $48 \pm 4$, respectively, and there were no significant changes between groups. The $\mathrm{Ct}$ value was read and the levels of the target mRNAs were calculated using the standard curve method as previously described (Wang et al. 2016). All primers in the present study were designed by Primer 3 software (Whitehead Institute for Biomedical Research, Cambridge, MA, USA). Forward and reverse primers were placed in different exons to minimize the effects of possible DNA contamination. These genes are luteinizing hormone receptor ( $L h c g r)$, scavenger receptor class B member 1 (Scarb1), Star, Cyp11a1, Hsd3b1, Cyp17a1, Hsd17b3, Srd5a1, Akr1c9, insulin-like 3 (Insl3), sulfotransferase 1A1 (Sult1a1) and cyclin D1 (Cond1). The primers were listed in Supplementary Table 1 (see section on supplementary data given at the end of this article).

\section{Western blotting analysis}

Immature Leydig cells after PDGF-BB treatment were homogenized and lysed. Protein concentrations in samples were measured using the Bio-Rad Protein Assay Kit (cat\# 500-0006; Bio-Rad) according to manufacturer's protocol. Bovine serum albumin was used as the protein standard. Samples (50 $\mu \mathrm{g}$ protein) were boiled in equal volumes of sample loading buffer, containing $20 \%$ glycerol, $5 \%$ sodium dodecyl sulfate, $3.1 \%$ dithiothreitol and $0.001 \%$ bromophenol blue. Samples were electrophoresed on $10 \%$ polyacrylamide gels containing sodium dodecyl sulfate. Proteins were electrophoretically transferred onto nitrocellulose membrane. After one-hour exposure to 5\% non-fat milk to block nonspecific binding, the membranes were incubated with the primary antibodies (1:1000 dilution) against LHCGR (Santa Cruz), CYP11A1 (Santa Cruz), CYP17A1 (Santa Cruz), STAR (Pterosaur Biotech, Hangzhou, Zhejiang, China) and actin $\beta$ (ACTB, Cell Signaling Technology). The membranes were then washed and incubated with a 1:1000 dilution of antirabbit or anti-goat antiserum (R\&D Systems) that was conjugated to horseradish peroxidase. The washing step was repeated, and immunoreactive bands were visualized by chemiluminescence using an ECL kit (Amersham). The density was scanned by ImageJ software. 


\section{Medium testosterone and} androstanediol measurement

The medium testosterone and androstanediol were fractionated using Sephadex LH-20 (Pharmacia Biotech, Uppsala, Sweden) column chromatography as previously described (Ge \& Hardy 1998). The elution system was chloroform-butane-ethanol (50:50:1, v/v/v) saturated with distilled water. Clear separation of testosterone and androstanediol in this system was confirmed using radiolabeled steroids (Ge \& Hardy 1998). The recovery rates following extraction and column separation were $75.6 \pm 4.2 \%$ for testosterone and $87.1 \pm 2.1 \%$ for DIOL, and these were used to correct the final concentration of testosterone and DIOL measured by RIA. Separated medium testosterone and androstanediol concentrations were measured with a tritium-based RIA as previously described (Cochran et al. 1981). Inter-assay and intraassay variations of the androgen were $7-8 \%$.

\section{Statistics}

All data are expressed as means \pm s.E.M. Data were subjected to analysis by one-way ANOVA test followed by ad hoc Tukey multiple comparisons to identify significant differences between the tested group and the control. Normalized signal values of microarray data were transformed to the log base 10, and an ANOVA analysis was performed. Differences were regarded as significant at $P<0.05$.

\section{Results}

\section{PDGF-BB stimulates androgen production in immature Leydig cells}

Immature Leydig cells are the cells at the intermediate stage during pubertal development of Leydig cells (Ge \& Hardy 1997, 1998), and they primarily produced androstanediol (Ge \& Hardy 1998). We investigated the effects of PDGF-BB on androgen production of rat immature Leydig cells. As shown in Fig. 1, PDGF-BB stimulated basal production of testosterone (Fig. 1A) or androstanediol (Fig. 1B) or testosterone plus androstanediol at $10 \mathrm{ng} / \mathrm{mL}$ (Fig. 1C). However, PDGF-BB did not affect the androgen production of rat immature Leydig cells under the stimulation of $\mathrm{LH}$ and 22R (Fig. 1D, E, F, G, H and I).

To dissect whether PDGF-BB exerts its action via PDGFRB, we used a PDGFRB inhibitor, PKI. 20nM PKI was used because it selectively inhibited PDGFRB $\left(\mathrm{IC}_{50}=4.2 \mathrm{nM}\right)$ over PDGFRA ( $\left.\mathrm{IC}_{50}=45 \mathrm{nM}\right)$ (Ho et al. 2005). PKI (20 nM) alone did not affect androgen production of immature Leydig cells. However, it reversed PDGF-BBstimulated testosterone (Fig. 2A), androstanediol (Fig. 2B)
Basal
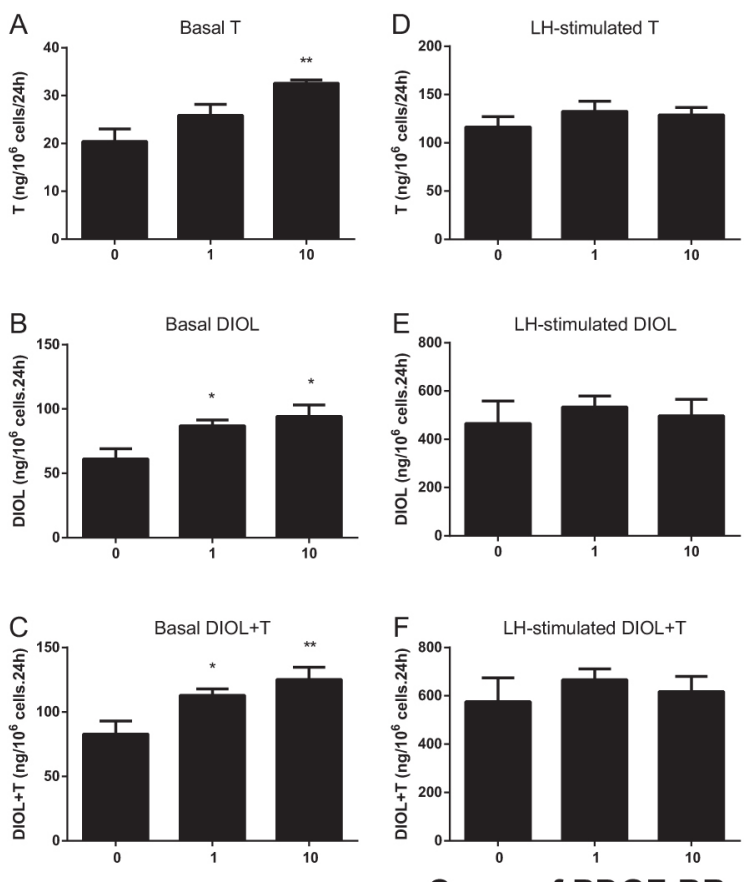

Conc

LH
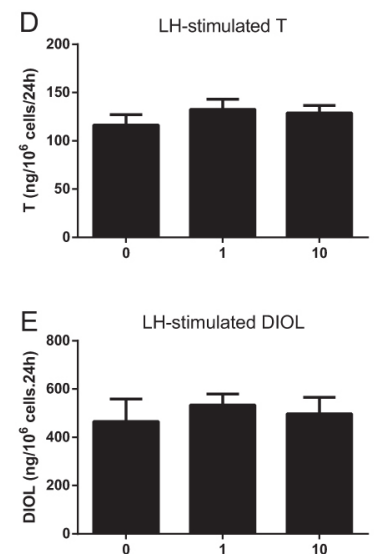
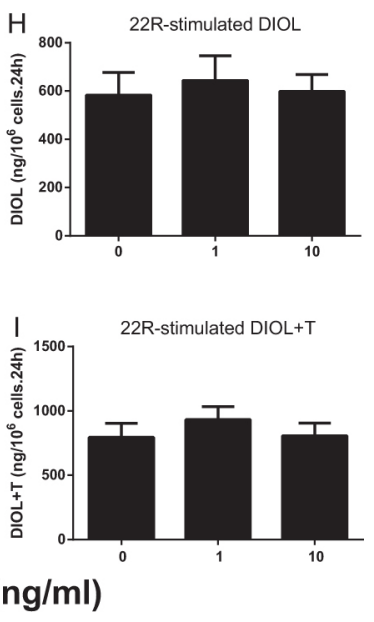

22R

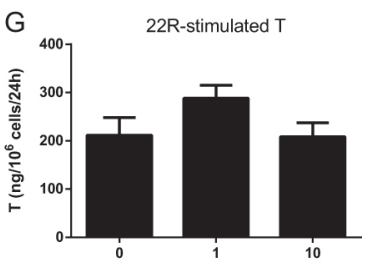

Effects of PDGF-BB on basal, LH- and 22R-hydroxycholesterol (22R)-stimulated androgen production in rat immature Leydig cells. Immature Leydig cells were cultured without (basal) or with $10 \mathrm{ng} / \mathrm{mL}$ LH (LH-stimulated) or $2 \mu \mathrm{M} 22 \mathrm{R}$ for $24 \mathrm{~h}$. Panel A, B and C, basal condition; panel $\mathrm{D}, \mathrm{E}$ and $\mathrm{F}$, LH-stimulated condition; panel G, H and I, 22R-stimulated condition. Mean \pm S.E.M., $n=8$. * **indicate significant difference at $P<0.05$ and $P<0.01$, respectively, when compared to the control (PDGF-BB, 0 ng/mL). 
A

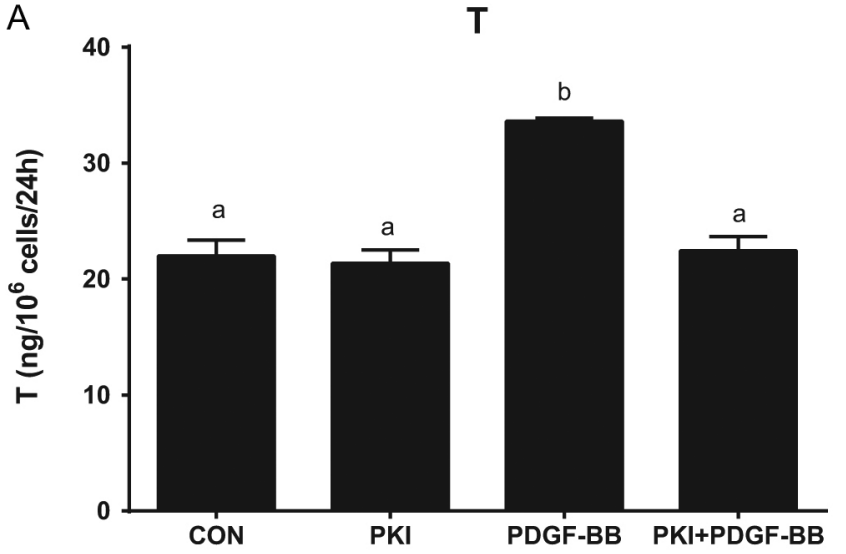

B

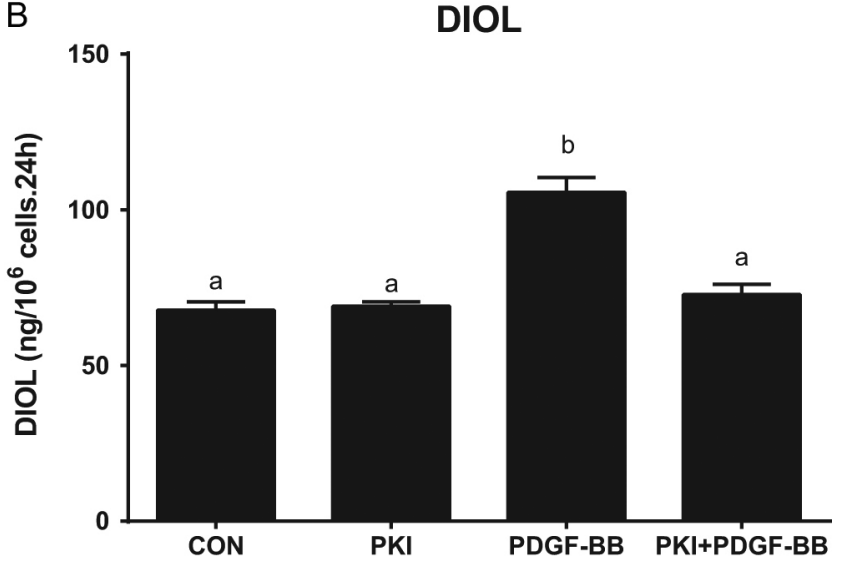

C

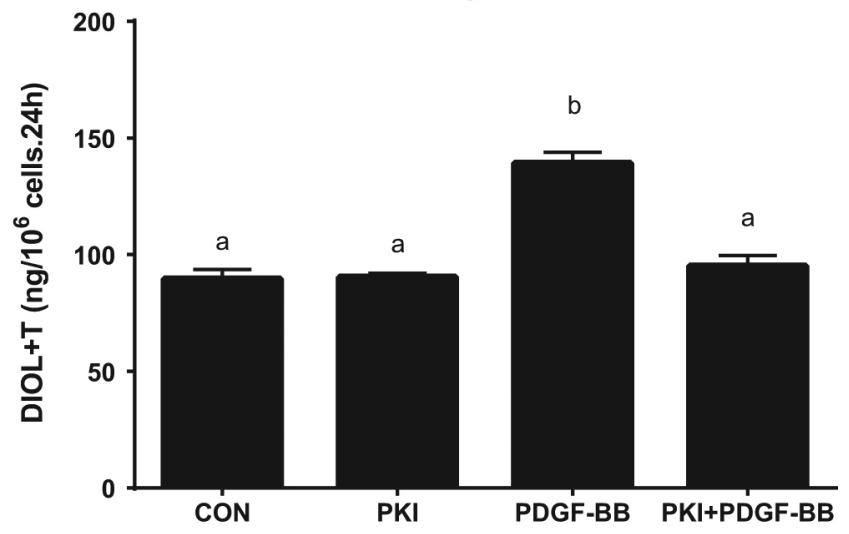

Figure 2

Effects of PDGF-BB and PDGFRB tyrosine kinase inhibitor IV (PKI) on basal androgen production in rat immature Leydig cells. Leydig cells were cultured in the basal condition with PKI $(20 \mathrm{nM})$ or PDGF-BB $(10 \mathrm{ng} / \mathrm{mL})$, or both (20nM PKI+10 ng PDGF-BB, PKI+PDGF-BB) for 24h. Panel A, testosterone (T); panel B, androstanediol (DIOL); panel C, T+DIOL. Mean \pm S.E.M., $n=8$. Identical letters between two groups indicate no significant difference at $P<0.05$.

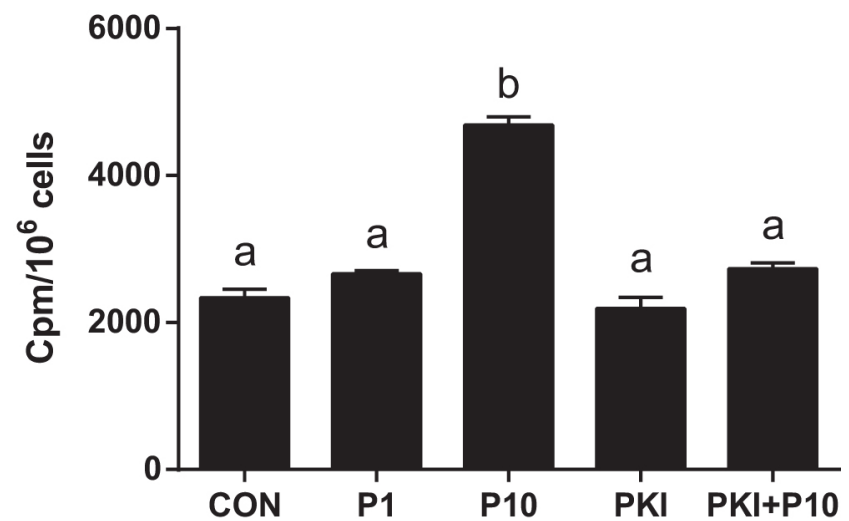

Figure 3

Effects of PDGF-BB and PDGFRB tyrosine kinase inhibitor IV (PKI) on thymidine incorporation into rat immature Leydig cells. Immature Leydig cells were cultured in the basal condition with PKI (20nM) or PDGF-BB (1 ng/mL P1; $10 \mathrm{ng} / \mathrm{mL}, \mathrm{P} 10)$, or both (20nM PKI+10 ng PDGF-BB, PKI+P10) for $24 \mathrm{~h}$. Mean \pm S.E.M., $n=3$. Identical letters between two groups indicate no significant difference at $P<0.05$.

and testosterone plus androstanediol (Fig. 2C). This indicates that PDGF-BB exerts its action via PDGFRB.

\section{PDGF-BB stimulates Leydig cell DNA synthesis}

Previous studies showed that immature Leydig cells were capable of proliferating (Ge \& Hardy 1997). PDGF-BB is also a possible growth factor to stimulate cell proliferation (Odeh et al. 2014). We measured immature Leydig cell DNA synthesis using ${ }^{3} \mathrm{H}$-thymidine incorporation. As shown in Fig. 3, PDGF-BB $(10 \mathrm{ng} / \mathrm{mL})$ stimulated thymidine incorporation. To dissect whether PDGF-BB exerts its action via PDGFRB, we treated the cells with PKI alone or together with PDGF-BB (10 ng/mL). PKI alone did not affect thymidine incorporation, but it reversed PDGFBB-stimulated thymidine incorporation (Fig. 3). This indicates that PDGF-BB exerts its proliferation-stimulating action via PDGFRB.

\section{Microarray analysis reveals PDGF-BB-mediated Leydig cell steroidogenesis}

We examined the effects of PDGF-BB on Leydig cell gene expression levels using microarray analysis of transcriptome. We analyzed a genome-wide expression containing 21,910 probes, of these probes, 9466 probes were detected in the control ( 2 fold about the noise background). Of 9466 probes, $10 \mathrm{ng} / \mathrm{mL}$ PDGF-BB treatment 
upregulated 197 gene expression by $\geq 2$ fold, in which 57 genes were also upregulated by $1 \mathrm{ng} / \mathrm{mL}$ PDGF-BB. Of the increased genes, we found that Star was significantly increased by 1.9- and 2.1-fold by 1 and $10 \mathrm{ng} / \mathrm{mL}$ PDGF-BB, respectively. $10 \mathrm{ng} / \mathrm{mL}$ PDGF-BB decreased 238 gene expression by $\geq 2$ fold, in which 58 genes were also decreased by $1 \mathrm{ng} / \mathrm{mL}$ PDGF-BB. Of decreased genes, Akr1c9 and Amhr2, which are biomarkers in the earlier stage of Leydig cells and significantly reduced during the maturation of immature Leydig cells were decreased by $\geq 2$ fold.

\section{RT-qPCR verification}

To validate microarray gene analysis, we used RT-qPCR verified the gene expression levels and specifically examined the effects of PDGF-BB on the expression levels of steroidogenesis-related and proliferation-related genes in rat immature Leydig cells, including Lhcgr, Scarb1, Star, Cyp11a1, Hsd3b1, Cyp17a1, Hsd17b3, Srd5a1, Akr1c9 and
Sult1a1 in different sets of samples. We also analyzed Leydig cell maturation biomarker Insl3 and cell proliferation biomarker Ccnd1. As shown in Fig. 4, PDGF-BB upregulated Star, Hsd17b3 and Insl3 expression levels at $\geq 1 \mathrm{ng} / \mathrm{mL}$. At $1 \mathrm{ng} / \mathrm{mL}$ PDGF-BB also increased expression of Cyp11a1 and Srd5a1, but it did not increase their expression levels at $10 \mathrm{ng} / \mathrm{mL}$. PDGF-BB at the higher concentration (10 ng/mL) significantly increased Ccnd1 expression level. PDGF-BB concentration-dependently decreased the expression levels of Akr1c9 and Sult1a1 but did not affect Scarb1, Hsd3b1 and Cyp17a1 expression levels. These data were in agreement with the changes of these genes in the microarray dataset. For example, in RT-qPCR data, 1 and $10 \mathrm{ng} / \mathrm{kg}$ PDGF-BB increased expression of Star by 2.78- and 2.45-fold, respectively while in microarray data they did by 1.9- and 2.1-fold, respectively. In RT-qPCR data, 1 and $10 \mathrm{ng} / \mathrm{kg}$ PDGF-BB decreased the expression of $A k r 1 c 9$ by 4- and 7.7-fold, respectively while in microarray data they did by 2- and 6-fold, respectively. These data indicate that PDGF-BB specifically regulates some gene expression levels.
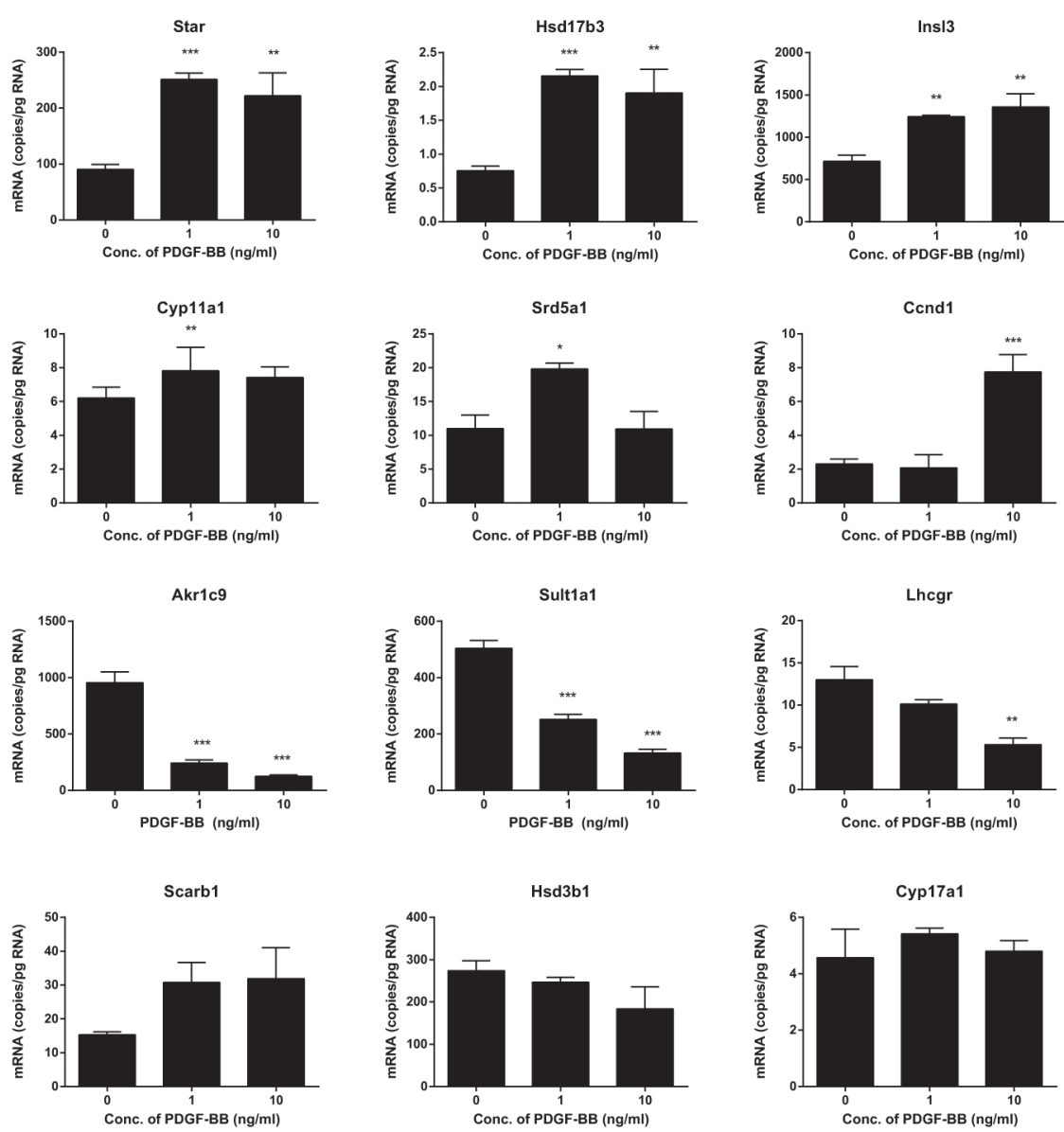

Figure 4

Effects of PDGF-BB on gene expression levels in rat immature Leydig cells. Immature Leydig cells were cultured in the basal condition with PDGF-BB ( 1 and $10 \mathrm{ng} / \mathrm{mL}$ ) for $24 \mathrm{~h}$. Three sets of genes were selected: genes with increased expression (Star, Hsd17b3, Ins/3, Cyp11a1, Srd5a1, and (cnd1), and genes with reduced expression (Akr1c9, Sult1a1, and Lhcgr) as well as unchanged genes (Scarb1, Hsd3b1, and Cyp17a1).

Mean \pm S.E.M., $n=4 .{ }^{*}, * *, * * *$ indicate significant difference at $P<0.05, P<0.01$, and $P<0.001$, respectively, when compared to the control (PDGF-BB, 0 ng/mL). 
A

\section{LHCGR STAR HSD17B3 ACTB}
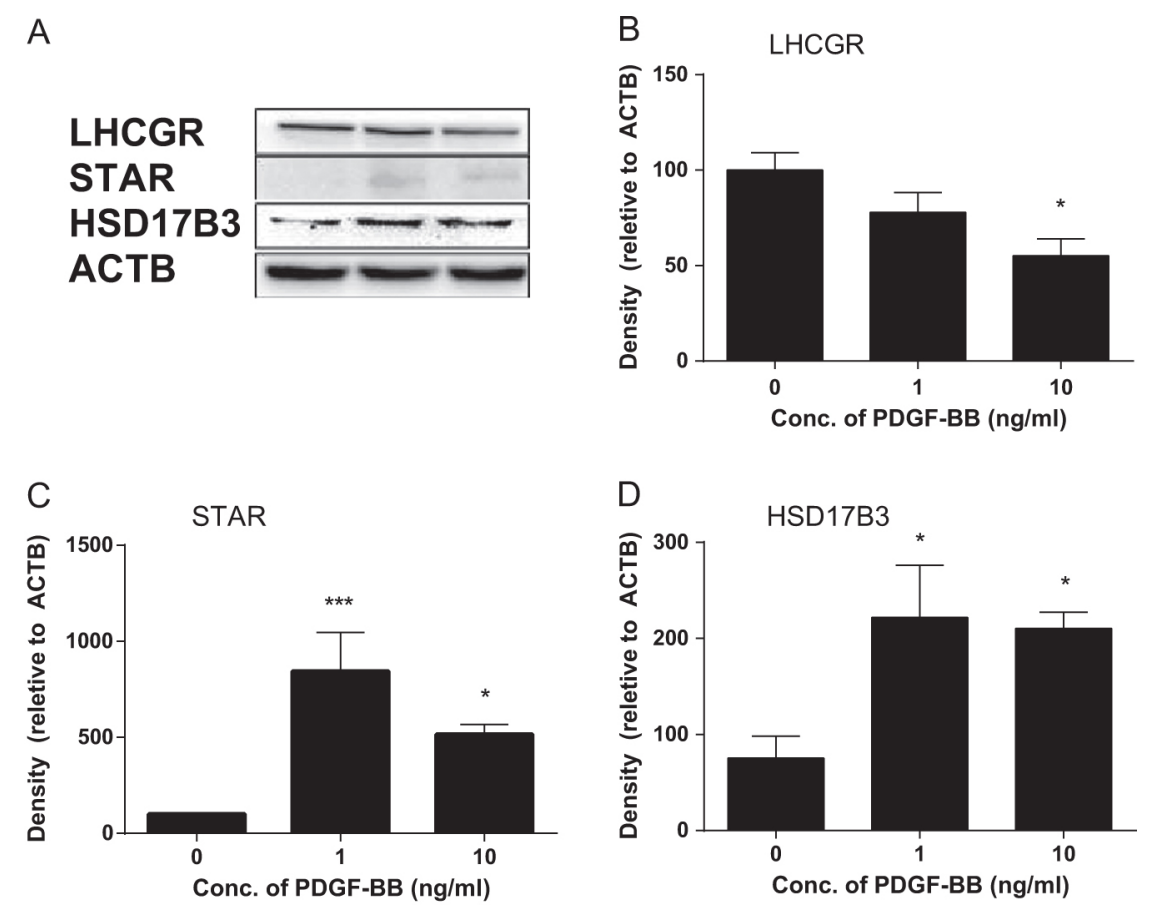

\section{Figure 5}

Effects of PDGF-BB on protein expression levels in rat immature Leydig cells. Immature Leydig cells were cultured in the basal condition with PDGF-BB $(1,10 \mathrm{ng} / \mathrm{mL})$ for $24 \mathrm{~h}$. LHCGR, STAR, and HSD17B3 protein levels were measured by Western blot. Panel $A$, Western blot images; panel $B, C$ and $D$, quantitative data. Mean \pm S.E.M., $n=4 . * * * *$ indicate significant difference at $P<0.05$ and $P<0.001$, respectively, when compared to the control (PDGF-BB, $0 \mathrm{ng} / \mathrm{mL}$ ).

\section{Effects of PDGF-BB on Leydig cell proteins}

We examined some specific protein (LHCGR, STAR and HSD17B3) levels in Leydig cells after PDGF-BB treatment (Fig. 5). We found that STAR $(P<0.001)$ and HSD17B3 $(P<0.05)$ levels were significantly increased by 8.4 -fold and 2.9-fold, respectively, at $\geq 1 \mathrm{ng} / \mathrm{mL}$ PDGF-BB, and LHCGR level was significantly decreased by 2-fold at $10 \mathrm{ng} / \mathrm{mL}$ PDGF-BB $(P<0.05)$. This was in agreement with the trend of their mRNA levels (e.g., Lhcgr was decreased by 2.4 fold by $10 \mathrm{ng} / \mathrm{mL}$ PDGF-BB).

\section{Major pathways of PDGF-BB}

We presented the genes with $\geq 4$-fold alteration in Table 1 (increased expression of genes) and Table 2 (decreased expression of genes). These genes were listed according to the GO analysis for biological pathway by Gene MicroArray Pathway Profiler 2.1. The increased expression of genes include cell structure proteins (Myo1b, Sgcg, Add2), extracellular matrix proteins (Lsamp, Col8a1, Mmp3, $I g s f 4$ ), growth factors and their receptors (Npy1r, Il1rl1, Igfbp3, Ucn2, Ednrb, Adora2b, Fst, Inhba, Gal, Gap43, Npw), intracellular signaling proteins (Phlda1, Wisp1, Serpinb2, Arhgdig, Rgs4, Egr1, Dusp6, Serinc2, Egr2, Ier2, Sh2b2, Dclk2), metabolism-related proteins (Upp1, Usp13, Cyp24a1, Akr1c18, Cpe, Rrm2, Enpp1, Ptgis, Serpine1, Mthfd1l, Car2), transcription factors (Maf, Runx1, Etv4, Hmga1, Fos), transporters (Slc17a1, Slc1a5, A2m). The decreased genes include cell structure proteins (LOC287167, Eln), growth factors and their receptors (Lgals5, Ccl20, Cfb, Cxcl11, Cxcl10, Cxcr7, Amhr2, Ccl12, Ccl11, Il18bp), intracellular signaling proteins (Pla2g2a, Ifit1, Ifit3, Tnnt2, Ubd, Omd, Gzmb, Defb52, Gbp5, Mx2, Mx1, Rgnef, Slfn3), metabolismrelated proteins (Akr1cl1, Akr1c9, Oas1a, Maob, Enpp2, Sult1a1, Cyp4f4).

Using GenMAPP2, we discovered several pathways that were specific to the regulation of PDGF-BB. As shown in Fig. 6 for steroidogenesis pathway, the expression level of Star was significantly increased and the expression levels of $A k r 1 c 9$ and Sult1a1 were significantly decreased. The expression levels of other steroidogenic enzymes were not changed (Supplementary Table 2).

The expression levels of cholesterol biosynthesis pathway (Hmgcs1, Idil, Fdps, Sqle, Cyp51, Sc4mol, and Dhcr7) were decreased by $2-4$ fold (Fig. 7). This indicates that after PDGF-BB treatment the de novo cholesterol biosynthesis is reduced.

\section{Discussion}

In the present study, we found that PDGF-BB positively regulated androgen production of rat immature Leydig cells by increasing the expression of Star and $H s d 17 b 3$, and decreasing the expression of $A k r 1 c 9$ and Sult1a1. This finding is novel.

Previous studies demonstrated that all cells in the Leydig cell lineage had PDGFRB (Ge et al. 2006, 
Table 1 The expression levels of genes that were increased by PDGF-BB.

\begin{tabular}{|c|c|c|c|c|}
\hline \multirow[b]{2}{*}{ Gene symbol } & \multirow[b]{2}{*}{ Gene name } & \multicolumn{3}{|c|}{ PDGF-BB (ng/mL) } \\
\hline & & 0 & 1 & 10 \\
\hline \multicolumn{5}{|l|}{ Structure protein } \\
\hline Myo1b & Myosin Ib & $9 \pm 1$ & $14 \pm 3(2)$ & $47 \pm 4(5) *$ \\
\hline Sgcg & Sarcoglycan gamma & $7 \pm 2$ & $14 \pm 2(2)$ & $33 \pm 2(5) *$ \\
\hline Add2 & Adducin 2 & $7 \pm 1$ & $12 \pm 3(2)$ & $26 \pm 3(4) *$ \\
\hline \multicolumn{5}{|c|}{ Extracellular matrix } \\
\hline Lsamp & Limbic system-associated membrane protein & $4 \pm 2$ & $14 \pm 1(3)$ & $40 \pm 7(10)^{*}$ \\
\hline Col8a1 & Procollagen type VIII $\alpha 1$ & $12 \pm 4$ & $31 \pm 6(3)$ & $96 \pm 6(8) *$ \\
\hline Mmp3 & Matrix metallopeptidase 3 & $996 \pm 63$ & $1625 \pm 38(2)$ & $5046 \pm 69(5) *$ \\
\hline Igsf4c & Immunoglobulin superfamily, member $4 \mathrm{C}$ & $29 \pm 2$ & $34 \pm 1(1)$ & $127 \pm 6(4) *$ \\
\hline \multicolumn{5}{|c|}{ Growth factors and receptors } \\
\hline Npy1r & Neuropeptide Y receptor Y1 & $1 \pm 2$ & $4 \pm 3(4)$ & $50 \pm 6(50) *$ \\
\hline Il1rl1 & Interleukin 1 receptor-like 1 & $47 \pm 12$ & $190 \pm 16(4)$ & $557 \pm 18(12) *$ \\
\hline Igfbp3 & Insulin-like growth factor binding protein 3 & $188 \pm 29$ & $310 \pm 8(2)$ & $1104 \pm 25(7) *$ \\
\hline Ǔcn2 & Urocortin 2 & $5 \pm 4$ & $17 \pm 2(3)$ & $37 \pm 3(7) *$ \\
\hline Ednrb & Endothelin receptor type B & $301 \pm 5$ & $588 \pm 18(2)$ & $1539 \pm 34(5) *$ \\
\hline Adora2b & Adenosine A2B receptor & $21 \pm 2$ & $40 \pm 5(2)$ & $73 \pm 3(4) *$ \\
\hline Fst & Follistatin & $37 \pm 11$ & $31 \pm 4(1)$ & $148 \pm 7(4) *$ \\
\hline Inhba & Inhibin beta-A & $14 \pm 2$ & $23 \pm 2(2)$ & $57 \pm 1(4) *$ \\
\hline Gal & Galanin & $22 \pm 3$ & $37 \pm 3(2)$ & $89 \pm 3(4) *$ \\
\hline Gap43 & Growth associated protein 43 & $69 \pm 2$ & $96 \pm 1(1)$ & $274 \pm 7(4) *$ \\
\hline Npw & Neuropeptide W & $39 \pm 3$ & $46 \pm 2(1)$ & $142 \pm 4(4) *$ \\
\hline \multicolumn{5}{|c|}{ Intracellular signaling } \\
\hline Phlda1 & Pleckstrin homology-like domain family A1 & $3 \pm 1$ & $7 \pm 2(2)$ & $39 \pm 2(15) *$ \\
\hline Wisp1 & WNT1 inducible signaling pathway protein 1 & $5 \pm 2$ & $12 \pm 2(2)$ & $84 \pm 2(15) *$ \\
\hline Serpinb2 & serine peptidase inhibitor, clade $B$, member 2 & $43 \pm 4$ & $66 \pm 5(2)$ & $314 \pm 8(7) *$ \\
\hline Arhgdig & Rho GDP dissociation inhibitor (GDI) gamma & $20 \pm 1$ & $49 \pm 2(2)$ & $141 \pm 5(7) *$ \\
\hline Rgs4 & Regulator of G-protein signaling 4 & $43 \pm 12$ & $97 \pm 5(2)$ & $267 \pm 20(6) *$ \\
\hline Egr1 & Early growth response 1 & $475 \pm 27$ & $737 \pm 33(2)$ & $2859 \pm 60(6) *$ \\
\hline Dusp6 & Dual specificity phosphatase 6 & $111 \pm 2$ & $126 \pm 3(1)$ & $614 \pm 20(6) *$ \\
\hline Serinc2 & Serine incorporator 2 & $117 \pm 12$ & $214 \pm 6(2)$ & $557 \pm 15(5) *$ \\
\hline Egr2 & Early growth response 2 & $317 \pm 29$ & $301 \pm 7(1)$ & $1466 \pm 33(5) *$ \\
\hline ler2 & Immediate early response 2 & $297 \pm 17$ & $442 \pm 11(2)$ & $1202 \pm 17(4) *$ \\
\hline Sh2b2 & SH2B adaptor protein 2 & $34 \pm 1$ & $78 \pm 4(2)$ & $133 \pm 4(4) *$ \\
\hline Dclk2 & Doublecortin-like kinase 2 & $18 \pm 4$ & $44 \pm 2(2)$ & $67 \pm 4(4) *$ \\
\hline \multicolumn{5}{|l|}{ Metabolism } \\
\hline Upp1 & Uridine phosphorylase 1 & $764 \pm 64$ & $1430 \pm 26(2)$ & $4332 \pm 131(6) *$ \\
\hline Usp13 & Ubiquitin specific protease 13 & $9 \pm 1$ & $38 \pm 4(4)$ & $50 \pm 2(5)$ \\
\hline Cyp24a1 & Cytochrome P450, subfamily 24 & $8 \pm 2$ & $18 \pm 3(2)$ & $44 \pm 3(5) *$ \\
\hline Akr1c18 & Aldo-keto reductase family 1 , member C18 & $9 \pm 1$ & $25 \pm 2(3)$ & $44 \pm 1(5) *$ \\
\hline Cpe & Carboxypeptidase E & $12 \pm 2$ & $34 \pm 5(3)$ & $52 \pm 4(4)$ \\
\hline Rrm2 & Ribonucleotide reductase M2 & $168 \pm 11$ & $289 \pm 10(2)$ & $640 \pm 38(4) *$ \\
\hline Enpp1 & Phosphodiesterase 1 & $532 \pm 121$ & $1324 \pm 48(2)$ & $2000 \pm 37(4) *$ \\
\hline Ptgis & Prostaglandin 12 & $525 \pm 68$ & $1133 \pm 88(2)$ & $2170 \pm 72(4) *$ \\
\hline Serpine1 & Serine peptidase inhibitor, clade E, member 1 & $323 \pm 28$ & $504 \pm 12(2)$ & $1195 \pm 25(4) *$ \\
\hline Mthfd1l & Methylenetetrahydrofolate dehydrogenase 1 & $46 \pm 11$ & $107 \pm 4(2)$ & $165 \pm 4(4) *$ \\
\hline Car2 & Carbonic anhydrase II & $156 \pm 2$ & $200 \pm 7(1)$ & $550 \pm 1(4) *$ \\
\hline \multicolumn{5}{|c|}{ Transcription factors } \\
\hline Maf & Monocyte to macrophage differentiation & $117 \pm 7$ & $213 \pm 6(2)$ & $810 \pm 16(7) *$ \\
\hline Runx1 & Runt related transcription factor 1 & $85 \pm 10$ & $202 \pm 17(2)$ & $511 \pm 10(6) *$ \\
\hline Etv4 & PREDICTED: ets variant gene 4 & $6 \pm 2$ & $8 \pm 1(1)$ & $35 \pm 5(5) *$ \\
\hline Hmga1 & High mobility group AT-hook 1 & $23 \pm 6$ & $43 \pm 2(2)$ & $117 \pm 1(5) *$ \\
\hline Fos & FBJ murine osteosarcoma viral oncogene & $66 \pm 1$ & $102 \pm 3(2)$ & $315 \pm 17(5) *$ \\
\hline Boll & Bol, boule-like & $54 \pm 8$ & $102 \pm 2(2)$ & $191 \pm 10(4) *$ \\
\hline \multicolumn{5}{|l|}{ Transporters } \\
\hline Slc17a1 & Solute carrier family 17 & $12 \pm 2$ & $21 \pm 3(2)$ & $56 \pm 1(5) *$ \\
\hline Slc1a5 & Solute carrier family 1 & $128 \pm 10$ & $196 \pm 6(2)$ & $504 \pm 23(4) *$ \\
\hline $\mathrm{A} 2 \mathrm{~m}$ & Alpha-2-macroglobulin & $19 \pm 3$ & $32 \pm 2(2)$ & $70 \pm 1(4) *$ \\
\hline \multicolumn{5}{|c|}{ Unknown proteins } \\
\hline RGD1560268 & Similar to AT motif-binding factor & $4 \pm 2$ & $19 \pm 2(6)$ & $25 \pm 1(7) *$ \\
\hline RGD1562464 & Similar to hypothetical protein A030011M19 & $6 \pm 2$ & $6 \pm 2(1)$ & $31 \pm 1(5) *$ \\
\hline LOC498829 & PREDICTED: Ab2-143 & $262 \pm 92$ & $718 \pm 38(3)$ & $1038 \pm 38(4) *$ \\
\hline RGD1562920 & PREDICTED: similar to Aig1 protein & $163 \pm 12$ & $252 \pm 7(2)$ & $596 \pm 7(4) *$ \\
\hline RGD1564216 & PREDICTED: similar to Myoferlin & $41 \pm 4$ & $64 \pm 6(2)$ & $152 \pm 3(4) *$ \\
\hline RGD1305534 & PREDICTED: similar to C210RF5 & $17 \pm 2$ & $33 \pm 4(2)$ & $64 \pm 3(4) *$ \\
\hline
\end{tabular}

() Fold changes compared to $0 \mathrm{ng} / \mathrm{PDGF}-\mathrm{BB}$.

*Indicates significant difference between 1 and $10 \mathrm{ng} / \mathrm{mL}$ PDGF-BB groups at $P<0.05$. 
Table 2 The expression levels of genes that were decreased by PDGF-BB.

\begin{tabular}{|c|c|c|c|c|}
\hline \multirow[b]{2}{*}{ Gene symbol } & \multirow[b]{2}{*}{ Gene name } & \multicolumn{3}{|c|}{ PDGF-BB (ng/mL) } \\
\hline & & 0 & 1 & 10 \\
\hline \multicolumn{5}{|l|}{ Cell structure } \\
\hline LOC287167 & Globin, alpha & $212 \pm 62$ & $35 \pm 8(-6)$ & $7 \pm 1(-27) *$ \\
\hline Eln & Elastin & $62 \pm 14$ & $44 \pm 4(-1)$ & $12 \pm 1(-5) *$ \\
\hline \multicolumn{5}{|c|}{ Cytokines, growth factors and receptors } \\
\hline Lgals5 & Lectin, galactose binding, soluble 5 & $502 \pm 207$ & $45 \pm 5(-11)$ & $23 \pm 1(-21) *$ \\
\hline $\mathrm{Ccl} 20$ & Chemokine ligand 20 & $373 \pm 151$ & $47 \pm 7(-8)$ & $21 \pm 3(-17) *$ \\
\hline Cfb & Complement factor B & $4882 \pm 1595$ & $1103 \pm 88(-4)$ & $326 \pm 11(-15) *$ \\
\hline Cxcl11 & Chemokine ligand 11 & $1926 \pm 976$ & $244 \pm 13(-8)$ & $110 \pm 14(-7) *$ \\
\hline $\mathrm{Cxcl} 10$ & Chemokine $(-\mathrm{C}-\mathrm{X}-\mathrm{C}$ motif) ligand 10 & $1921 \pm 748$ & $598 \pm 114(-3)$ & $344 \pm 4(-6) *$ \\
\hline Cxcr7 & Chemokine (-C-X-C motif) receptor 7 & $306 \pm 20$ & $196 \pm 8(-1)$ & $59 \pm 4(-5) *$ \\
\hline Amhr2 & Anti-Mullerian hormone receptor 2 & $80 \pm 20$ & $27 \pm 2(-3)$ & $15 \pm 6(-5) *$ \\
\hline $\mathrm{Ccl} 12$ & Chemokine (-C-C motif) ligand 12 & $116 \pm 52$ & $35 \pm 1(-3)$ & $25 \pm 3(-4) *$ \\
\hline $\mathrm{Ccl} 11$ & Chemokine (-C-C motif) ligand 11 & $542 \pm 118$ & $220 \pm 9(-2)$ & $122 \pm 9(-4) *$ \\
\hline Il18bp & Interleukin 18 binding protein & $196 \pm 53$ & $89 \pm 14(-2)$ & $45 \pm 3(-4) *$ \\
\hline \multicolumn{5}{|l|}{ Intracellular signing } \\
\hline Pla2g2a & Phospholipase A2, group IIA & $1969 \pm 809$ & $246 \pm 4(-4)$ & $24 \pm 3(-79) *$ \\
\hline Ifit1 & IFN-induced/tetratricopeptide repeats 1 & $356 \pm 113$ & $129 \pm 38(-3)$ & $25 \pm 2(-14) *$ \\
\hline Ifit3 & IFN-induced/tetratricopeptide repeats 3 & $257 \pm 106$ & $76 \pm 21(-3)$ & $19 \pm 1(-13) *$ \\
\hline Tnnt2 & Troponin T type 2 & $165 \pm 69$ & $25 \pm 7(-4)$ & $16 \pm 3(-10) *$ \\
\hline Ubd & Ubiquitin D & $2856 \pm 1274$ & $638 \pm 93(-4)$ & $284 \pm 18(-10) *$ \\
\hline Omd & Osteomodulin & $81 \pm 8$ & $29 \pm 2(-3)$ & $8 \pm 1(-9) *$ \\
\hline Gzmb & Granzyme B & $98 \pm 25$ & $32 \pm 4(-3)$ & $11 \pm 3(-8) *$ \\
\hline Defb52 & Defensin beta 52 & $156 \pm 73$ & $20 \pm 3(-7)$ & $19 \pm 5(-8)$ \\
\hline Gbp5 & Guanylate nucleotide binding protein 5 & $292 \pm 122$ & $67 \pm 7(-4)$ & $37 \pm 3(-8) *$ \\
\hline$M \times 2$ & Myxovirus resistance 2 & $1265 \pm 517$ & $374 \pm 25(-3)$ & $165 \pm 6(-7) *$ \\
\hline Mx1 & Myxovirus resistance 1 & $1562 \pm 601$ & $495 \pm 110(-3)$ & $293 \pm 11(-5) *$ \\
\hline Rgnef & Rho-guanine nucleotide exchange factor & $89 \pm 12$ & $44 \pm 2(-2)$ & $17 \pm 1(-5) *$ \\
\hline SIfn3 & Schlafen 3 & $822 \pm 389$ & $308 \pm 36(-2)$ & $199 \pm 10(-4) *$ \\
\hline \multicolumn{5}{|l|}{ Metabolism } \\
\hline Akr1cl1 & Aldo-keto reductase 1, member $C$ like 1 & $62 \pm 9$ & $43 \pm 3(-1)$ & $8 \pm 2(-7) *$ \\
\hline Akr1c9 & 3-Alpha-hydroxysteroid dehydrogenase & $1507 \pm 338$ & $657 \pm 24(-2)$ & $241 \pm 4(-6) *$ \\
\hline Oas1a & 2'-5' Oligoadenylate synthetase $1 \mathrm{~A}$ & $190 \pm 71$ & $57 \pm 9(-3)$ & $29 \pm 2(-6) *$ \\
\hline Maob & Monoamine oxidase B & $74 \pm 9$ & $50 \pm 6(-1)$ & $14 \pm 1(-5) *$ \\
\hline Enpp2 & Ectonucleotide pyrophosphatase & $1469 \pm 485$ & $466 \pm 36(-4)$ & $356 \pm 19(-4)$ \\
\hline Sult1a1 & Sulfotransferase family, cytosolic, 1A1 & $948 \pm 76$ & $561 \pm 17(-2)$ & $232 \pm 3(-4) *$ \\
\hline Cyp4f4 & Cytochrome P450, family 4, subfamily f4 & $82 \pm 14$ & $48 \pm 2(-2)$ & $20 \pm 1(-4) *$ \\
\hline \multicolumn{5}{|l|}{ Unknown proteins } \\
\hline LOC498795 & Coiled-coil domain containing 3 & $92 \pm 24$ & $39 \pm 5(-2)$ & $6 \pm 1(-18) *$ \\
\hline RGD1559565 & EF hand domain containing 1 & $55 \pm 7$ & $22 \pm 2(-2)$ & $4 \pm 2(-13) *$ \\
\hline LOC 497812 & Hypothetical gene supported & $124 \pm 38$ & $80 \pm 40(-1)$ & $13 \pm 2(-9) *$ \\
\hline RGD1564008 & Similar to dapper 1 & $203 \pm 39$ & $81 \pm 5(-2)$ & $26 \pm 2(-7) *$ \\
\hline RGD1563645 & Similar to granzyme $\mathrm{C}$ & $231 \pm 27$ & $103 \pm 3(-2)$ & $38 \pm 3(-6) *$ \\
\hline RGD1309362 & Similar to interferon-inducible GTPase & $514 \pm 102$ & $175 \pm 10(-2)$ & $89 \pm 9(-6) *$ \\
\hline LOC312688 & Ubiquitin specific protease UBP43 & $121 \pm 53$ & $55 \pm 8(-2)$ & $22 \pm 3(-5) *$ \\
\hline RGD1310093 & Hypothetical protein FLJ11354 & $116 \pm 42$ & $40 \pm 2(-3)$ & $22 \pm 5(-5) *$ \\
\hline LOC497841 & Hypothetical gene NM_016994 & $145 \pm 34$ & $76 \pm 6(-2)$ & $28 \pm 3(-5) *$ \\
\hline RGD1563091 & Similar to OEF2 & $157 \pm 45$ & $62 \pm 10(-2)$ & $33 \pm 4(-5) *$ \\
\hline Plac8_predicted & Placenta-specific 8 & $2103 \pm 494$ & $1041 \pm 70(-2)$ & $475 \pm 11(-4) *$ \\
\hline LOC500297 & Similar to env precursor & $211 \pm 33$ & $148 \pm 6(-1)$ & $49 \pm 3(-4) *$ \\
\hline RGD1561444 & Similar to RIKEN cDNA 9530077C05 & $118 \pm 10$ & $86 \pm 9(-1)$ & $29 \pm 4(-4) *$ \\
\hline
\end{tabular}

() Fold changes compared to $0 \mathrm{ng} / \mathrm{mL}$ PDGF-BB.

*Indicates significant difference between 1 and $10 \mathrm{ng} / \mathrm{mL}$ PDGF-BB groups at $P<0.05$.

Schmahl et al. 2008, Bergeron et al. 2011, Odeh et al. 2014). Using the knockout mice with Leydig cell specific knockout of PDGFRB, it was demonstrated that PDGFRB was important for maintenance of Leydig cell number at adulthood (Schmahl et al. 2008). In the present study, we demonstrated that rat immature Leydig cells are responsive to PDGF-BB. During the maturation of immature into adult Leydig cells, the expression levels 


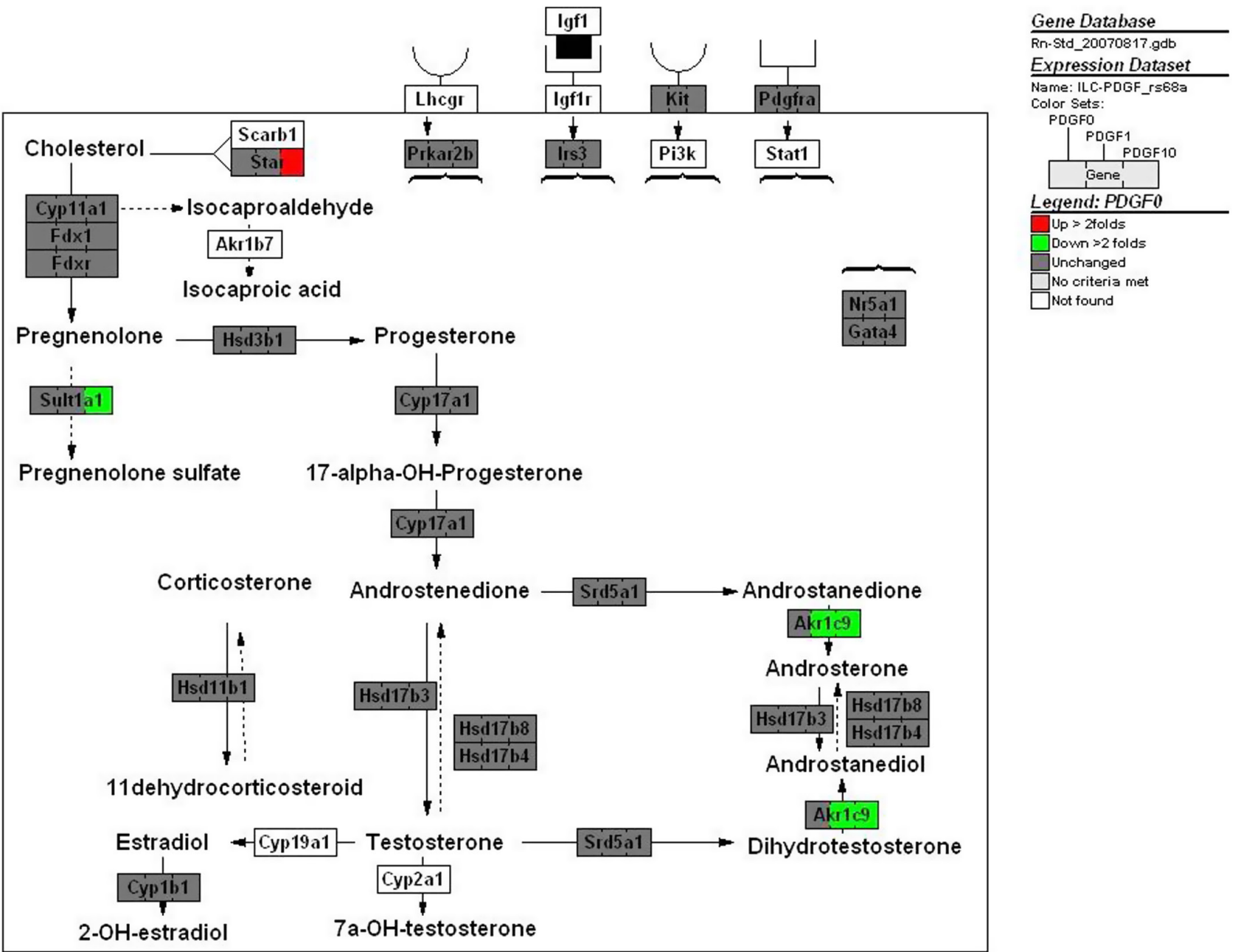

Figure 6

Steroidogenesis pathway in at immature Leydig cells after PDGF-BB treatment. Star level was significantly increased by 2 fold. Akr1c9 and Sult1a1 levels were significantly decreased by 2-fold. PDGF0, PDGF1 and PDGF10 represent the doses of 0,1 and $10 \mathrm{ng} / \mathrm{mL}$.

of Star and androgen-biosynthetic enzymes (Cyp11a1, $H s d 3 b 1, C y p 17 a 1$, and $H s d 17 b 3$ ) are increased while the androgen-metabolizing enzymes (Srd5a1, Akr1c9, Sult1a1) are decreased (Ge \& Hardy 1998, Ge et al. 2005, Zhang et al. 2013). Indeed, we found that after $24 \mathrm{~h}$ of treatment PDGF-BB concentration-dependently increased the expression levels of Star and $H s d 17 b 3$ while decreased that of Akr1c9 and Sult1a1 (Fig. 6 and Tables 1 and 2).

The Star mRNA (Fig. 4) and STAR protein (Fig. 5) levels were remarkably increased. STAR mediates the ratelimiting step in the androgen biosynthesis in the Leydig cells, in which it serves the carrier to transport cholesterol, the substrate for steroidogenesis, from the Leydig cell mitochondrial outer membrane into the inner membrane (Zhou et al. 1991, Lemaire et al. 2006), where CYP11A1 cleaves the cholesterol side chain to form pregnenolone. There are many results to point to the crucial role of
STAR in regulating steroidogenesis (reviewed in Thomas et al. 1988). Many signaling pathways, including protein kinase A (PKA), protein kinase $\mathrm{C}$, and nuclear receptor, are involved in the regulation of transcription of Star gene (reviewed in De Jong et al. 2002). The Star gene is transcriptionally regulated via the concerted action of multiple proteins that bind directly or indirectly to the DNA regulatory elements (Manna et al. 2003, 2004a,b) Transcriptional activation by cAMP signaling after LH-stimulation is mediated through the interaction of the cAMP-response element (CRE)-binding protein (CREB) with CRE-like elements including an overlapping CRE2/AP-1 motif (Fos/Jun) in the Star gene promoter because the promoter lacks the classic conserved CRE (TGACGTCA) (Manna et al. 2003, 2004a,b). The CREB/ activating transcription factor (ATF) and Fos/Jun interact with themselves or each other to form selective dimers 


\section{Cholesterol Biosynthesis}

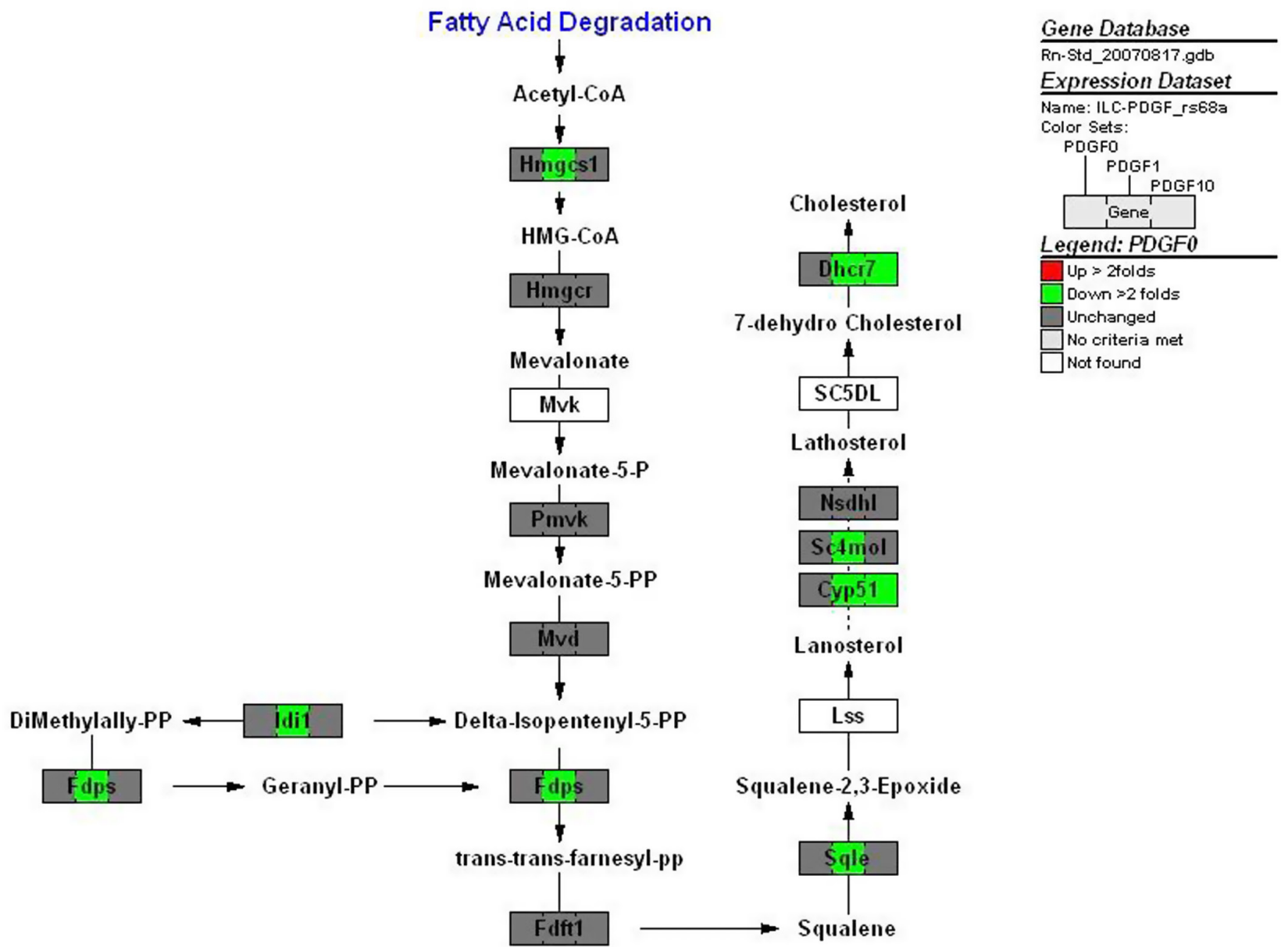

Figure 7

Cholesterol biosynthesis pathway of immature Leydig cells after PDGF-BB treatment. Cholesterol biosynthesis genes (Hmgcs1, Idil, Fdps, Sqle, Cyp51, Sc4mol, and Dhcr7) were decreased by 2-4 fold. PDGF0, PDGF1 and PDGF10 represent the doses of 0,1 and $10 \mathrm{ng} / \mathrm{mL}$.

that bind to closely related CRE and AP-1 sequences and induce transcriptional responses. CREB binds to DNA as a homodimer and it is activated after phosphorylation at Ser133 of CREB by several kinases including PKA (Clem et al. 2005). Fos members bind to DNA as heterodimers with Jun proteins (Wagner 2001). Expression of Fos is regulated by many extracellular signal factors. FOS has been demonstrated to bind to the CRE2/AP-1 motif alone transactivating basal Star gene transcription. In the present study, we demonstrated that Fos expression level was increased 2 fold and 5 fold by 1 and $10 \mathrm{ng} / \mathrm{mL}$ PDGF-BB, respectively (Table 1). This suggests that PDGF-BB increases Star expression via increasing the Fos expression. Interestingly, when PDGF-BB together with LH treatment was performed, androgen production was not changed. The exact mechanism is not unclear. We speculated that LH already maximally increased androgen production, which was 5 fold compared to the basal level and this may mask the stimulatory effects of PDGF-BB.

We also found that the significant decrease of $A k r 1 c 9$ even at $1 \mathrm{ng} / \mathrm{mL}$ PDGF-BB. Akr1c9 encodes AKR1C9 ( $3 \alpha$-hydroxysteroid dehydrogenase), which catalyzes the metabolism of dihydrotestosterone, a potent androgen, into androstanediol, a weak androgen. The expression level of Akr1c9 is the highest in the progenitor Leydig cells and gradually declines and reaches the lowest level in adult Leydig cells (Shan et al. 1995, Ge \& Hardy 1998). This indicates that PDGF-BB promotes the development of immature Leydig cells. The regulation of Akr1c9 expression is far from clear in Leydig cells. A previous study demonstrated that both LH and androgen can increase $A k r 1 c 9$ expression (Shan et al. 1995). Interestingly, liver Akr1c9 gene promote region contains AP-1 site (Lin \& Penning 1995), whether FOS can regulate via this 
site awaits for a further investigation in the future. In our study, we also found that Sult1a1 was significantly reduced. SULT1A1 is an enzyme that catalyzes the sulfate conjugation of many steroid hormones, neurotransmitters, drugs, and xenobiotic compounds.

At the higher concentration (10 ng/mL), PDGF-BB also stimulated the proliferation of rat immature Leydig cells as evidence of increased incorporation of thymidine into these cells (Fig. 3). Interestingly, PDGF-BB is a potent stimulator of the mitosis of stem Leydig cells (Li et al. 2016). In the present study, the Ccnd 1 expression level was significantly increased by $10 \mathrm{ng} / \mathrm{mL}$ PDGF-BB, indicating that this growth factor can regulate the cell proliferation via increasing expression of CCND1. PDGF-BB has been reported to increase Ccnd1 expression in mesenchymal stem cells for their proliferation (Gharibi et al. 2012).

There are not many studies about the effects of PDGF-BB on steroidogenic cells. One study showed that PDGF-BB inhibited the activity of SRD5A1 and HSD3B1 in cultured Leydig cells from (immature Leydig cells) 25-dayold rat testis (Murono \& Washburn 1990), while another study showed it increased LH-stimulated T production in vitro (Loveland et al. 1993, Risbridger 1993). PDGF-BB also inhibited stem Leydig cell commitment into the Leydig cell lineage in rats by reducing testosterone production after the stem Leydig cells were cultured in the presence of LH and ITS (Odeh et al. 2014). However, in the present study, we clearly demonstrated that PDGF-BB alone stimulated androgen production in rat immature Leydig cells (Fig. 1). This indicates that the effects of PDGF-BB on Leydig cell development depending on the stages of Leydig cells. The pathway of PDGF-BB stimulated steroidogenesis is not clear until the present study, in which we demonstrated that it increased the expression levels of Star and Hsd17b3. PDGF-BB might have significant physiological action on Leydig cell development since Leydig cell conditional 1 knockout of Pdgfrb in mice led to a significant reduction of Leydig cell number in the fetal testis (Schmahl et al. 2008). However, the exact concentration of PDGF-BB in the pubertal rat testis is still not known. Furthermore study is required to identify its physiological level.

In conclusion, the present study demonstrated that PDGF-BB regulated the steroidogenesis of immature Leydig cells by increasing the expression levels of Star and steroidogenic enzyme gene Hsd17b3.

\section{Supplementary data}

This is linked to the online version of the paper at https://doi.org/10.1530/ JME-17-0222.
Declaration of interest

The authors declare that there is no conflict of interest that could be perceived as prejudicing the impartiality of the research reported.

\section{Funding}

The present study was supported by NSFC ( 81730042 to R S G, 81601266 to $X$ L), Zhejiang Provincial NSFC (LY15H310008 to R S G).

\section{References}

Basciani S, Mariani S, Spera G \& Gnessi L 2010 Role of platelet-derived growth factors in the testis. Endocrine Reviews 31 916-939. (https://doi.org/10.1210/er.2010-0004)

Bergeron F, Bagu ET \& Tremblay JJ 2011 Transcription of platelet-derived growth factor receptor alpha in Leydig cells involves specificity protein 1 and 3. Journal of Molecular Endocrinology 46 125-138. (https://doi.org/10.1530/JME-10-0145)

Betsholtz C, Karlsson L \& Lindahl P 2001 Developmental roles of platelet-derived growth factors. Bioessays 23 494-507. (https://doi. org/10.1002/bies.1069)

Brennan J, Tilmann C \& Capel B 2003 Pdgfr-alpha mediates testis cord organization and fetal Leydig cell development in the XY gonad. Genes and Development 17 800-810. (https://doi.org/10.1101/ gad.1052503)

Chen H, Ge RS \& Zirkin BR 2009 Leydig cells: from stem cells to aging. Molecular and Cellular Endocrinology 306 9-16. (https://doi. org/10.1016/j.mce.2009.01.023)

Clem BF, Hudson EA \& Clark BJ 2005 Cyclic adenosine 3',5'-monophosphate (cAMP) enhances cAMP-responsive element binding (CREB) protein phosphorylation and phospho-CREB interaction with the mouse steroidogenic acute regulatory protein gene promoter. Endocrinology 146 1348-1356. (https://doi. org/10.1210/en.2004-0761)

Cochran RC, Ewing LL \& Niswender GD 1981 Serum levels of folliclestimulating hormone, prolactin, testosterone, $5 \alpha$-dihydrotestosterone, $5 \alpha$-androstane- $3 \alpha, 17 \beta$-diol, $5 \alpha$-androstane$3 \beta, 17 \beta$-diol and $17 \beta$-estradiol from male beagles with spontaneous or induced benign prostatic hyperplasia. Investigative Urology 19 142-147.

De Jong WH, Tentij M, Spiekstra SW, Vandebriel RJ \& Van Loveren H 2002 Determination of the sensitising activity of the rubber contact sensitisers TMTD, ZDMC, MBT and DEA in a modified local lymph node assay and the effect of sodium dodecyl sulfate pretreatment on local lymph node responses. Toxicology 176 123-134. (https://doi. org/10.1016/S0300-483X(02)00131-2)

Feng Y, Zhang P, Zhang Z, Shi J, Jiao Z \& Shao B 2016 Endocrine disrupting effects of triclosan on the placenta in pregnant rats PLOS ONE 11 e0154758. (https://doi.org/10.1371/journal. pone.0154758)

Ge RS \& Hardy MP 1997 Decreased cyclin A2 and increased cyclin G1 levels coincide with loss of proliferative capacity in rat Leydig cells during pubertal development. Endocrinology 138 3719-3726. (https://doi.org/10.1210/endo.138.9.5387)

Ge RS \& Hardy MP 1998 Variation in the end products of androgen biosynthesis and metabolism during postnatal differentiation of rat Leydig cells. Endocrinology 139 3787-3795. (https://doi.org/10.1210/ endo.139.9.6183)

Ge RS \& Hardy MP 2007 Regulation of Leydig cells during pubertal development. In The Leydig Cell in Health and Disease, pp 55-70. Eds AH Payne \& MP Hardy. Totowa, NJ, USA: Humana Press.

Ge RS, Dong Q, Sottas CM, Chen H, Zirkin BR \& Hardy MP 2005 Gene expression in rat leydig cells during development from the 
progenitor to adult stage: a cluster analysis. Biology of Reproduction $\mathbf{7 2}$ 1405-1415. (https://doi.org/10.1095/biolreprod.104.037499)

Ge RS, Dong Q, Sottas CM, Papadopoulos V, Zirkin BR \& Hardy MP 2006 In search of rat stem Leydig cells: identification, isolation, and lineage-specific development. PNAS 103 2719-2724. (https://doi. org/10.1073/pnas.0507692103)

Gharibi B, Ghuman MS \& Hughes FJ 2012 Akt- and Erk-mediated regulation of proliferation and differentiation during PDGFRbetainduced MSC self-renewal. Journal of Cellular and Molecular Medicine 16 2789-2801. (https://doi.org/10.1111/j.1582-4934.2012.01602.x)

Gnessi L, Emidi A, Farini D, Scarpa S, Modesti A, Ciampani T, Silvestroni L \& Spera G 1992 Rat Leydig cells bind platelet-derived growth factor through specific receptors and produce platelet-derived growth factor-like molecules. Endocrinology 130 2219-2224. (https://doi.org/10.1210/endo.130.4.1312451)

Gnessi L, Emidi A, Jannini EA, Carosa E, Maroder M, Arizzi M, Ulisse S \& Spera G 1995 Testicular development involves the spatiotemporal control of PDGFs and PDGF receptors gene expression and action. Journal of Cell Biology 131 1105-1121. (https://doi.org/10.1083/ jcb.131.4.1105)

Griffin DK, Ellis PJ, Dunmore B, Bauer J, Abel MH \& Affara NA 2010 Transcriptional profiling of luteinizing hormone receptor-deficient mice before and after testosterone treatment provides insight into the hormonal control of postnatal testicular development and Leydig cell differentiation. Biology of Reproduction 82 1139-1150. (https://doi.org/10.1095/biolreprod.109.082099)

Hardy MP, Gelber SJ, Zhou ZF, Penning TM, Ricigliano JW, Ganjam VK, Nonneman D \& Ewing LL 1991 Hormonal control of Leydig cell differentiation. Annals of the New York Academy of Sciences $\mathbf{6 3 7}$ 152-163. (https://doi.org/10.1111/j.1749-6632.1991.tb27308.x)

Hardy MP, Zirkin BR \& Ewing LL 1989 Kinetic studies on the development of the adult population of Leydig cells in testes of the pubertal rat. Endocrinology 124 762-770. (https://doi.org/10.1210/ endo-124-2-762)

Ho CY, Ludovici DW, Maharoof US, Mei J, Sechler JL, Tuman RW, Strobel ED, Andraka L, Yen HK, Leo G, et al. 2005 (6,7-Dimethoxy2,4-dihydroindeno[1,2-c]pyrazol-3-yl)phenylamines: platelet-derived growth factor receptor tyrosine kinase inhibitors with broad antiproliferative activity against tumor cells. Journal of Medicinal Chemistry 48 8163-8173. (https://doi.org/10.1021/jm050680m)

Lemaire G, Mnif W, Mauvais P, Balaguer P \& Rahmani R 2006 Activation of alpha- and beta-estrogen receptors by persistent pesticides in reporter cell lines. Life Sciences 79 1160-1169. (https://doi. org/10.1016/j.lfs.2006.03.023)

Li H, Papadopoulos V, Vidic B, Dym M \& Culty M 1997 Regulation of rat testis gonocyte proliferation by platelet-derived growth factor and estradiol: identification of signaling mechanisms involved. Endocrinology 138 1289-1298. (https://doi.org/10.1210/ endo.138.3.5021)

Li X, Wang Z, Jiang Z, Guo J, Zhang Y, Li C, Chung J, Folmer J, Liu J, Lian Q, et al. 2016 Regulation of seminiferous tubule-associated stem Leydig cells in adult rat testes. PNAS 113 2666-2671. (https://doi. org/10.1073/pnas.1519395113)

Lin HK \& Penning TM 1995 Cloning, sequencing, and functional analysis of the $5^{\prime}$-flanking region of the rat 3 alphahydroxysteroid/dihydrodiol dehydrogenase gene. Cancer Research 55 4105-4113.

Lin H, Lian QQ, Hu GX, Jin Y, Zhang Y, Hardy DO, Chen GR, Lu ZQ, Sottas CM, Hardy MP, et al. 2009 In utero and lactational exposures to diethylhexyl-phthalate affect two populations of leydig cells in male long-evans rats. Biology of Reproduction $\mathbf{8 0} 882-888$. (https://doi.org/10.1095/biolreprod.108.072975)

Loveland KL, Hedger MP, Risbridger G, Herszfeld D \& De Kretser DM 1993 Identification of receptor tyrosine kinases in the rat testis. Molecular Reproduction and Development 36 440-447. (https://doi. org/10.1002/mrd.1080360406)
Manna PR, Eubank DW, Lalli E, Sassone-Corsi P \& Stocco DM 2003 Transcriptional regulation of the mouse steroidogenic acute regulatory protein gene by the cAMP response-element binding protein and steroidogenic factor 1. Journal of Molecular Endocrinology 30 381-397. (https://doi.org/10.1677/jme.0.0300381)

Manna PR, Eubank DW \& Stocco DM 2004a Assessment of the role of activator protein-1 on transcription of the mouse steroidogenic acute regulatory protein gene. Molecular Endocrinology 18 558-573. (https://doi.org/10.1210/me.2003-0223)

Manna PR, Huhtaniemi IT \& Stocco DM 2004b Detection of hCG responsive expression of the steroidogenic acute regulatory protein in mouse leydig cells. Biological Procedures Online 6 83-93. (https://doi.org/10.1251/bpo76)

Mendis-Handagama SM \& Ariyaratne HB 2001 Differentiation of the adult Leydig cell population in the postnatal testis. Biology of Reproduction 65 660-671. (https://doi.org/10.1095/ biolreprod65.3.660)

Murono EP \& Washburn AL 1990 Platelet derived growth factor inhibits 5 alpha-reductase and delta 5-3 beta-hydroxysteroid dehydrogenase activities in cultured immature Leydig cells. Biochemical and Biophysical Research Communications 169 1229-1234. (https://doi. org/10.1016/0006-291X(90)92028-X)

Odeh HM, Kleinguetl C, Ge R, Zirkin BR \& Chen H 2014 Regulation of the proliferation and differentiation of leydig stem cells in the adult testis. Biology of Reproduction 90 123-128 (https://doi.org/10.1095/ biolreprod.114.117473)

Payne AH, Wong KL \& Vega MM 1980 Differential effects of single and repeated administrations of gonadotropins on luteinizing hormone receptors and testosterone synthesis in two populations of Leydig cells. Journal of Biological Chemistry 255 7118-7122.

Risbridger GP 1993 Discrete stimulatory effects of platelet-derived growth factor (PDGF-BB) on Leydig cell steroidogenesis. Molecular and Cellular Endocrinology 97 125-128. (https://doi.org/10.1016/03037207(93)90218-9)

Schmahl J, Rizzolo K \& Soriano P 2008 The PDGF signaling pathway controls multiple steroid-producing lineages. Genes and Development 22 3255-3267. (https://doi.org/10.1101/gad.1723908)

Shan L, Hardy DO, Catterall JF \& Hardy MP 1995 Effects of luteinizing hormone (LH) and androgen on steady state levels of messenger ribonucleic acid for $\mathrm{LH}$ receptors, androgen receptors, and steroidogenic enzymes in rat Leydig cell progenitors in vivo. Endocrinology 136 1686-1693. (https://doi.org/10.1210/ endo.136.4.7895679)

Thomas JL, Berko EA, Faustino A, Myers RP \& Strickler RC 1988 Human placental 3 beta-hydroxy-5-ene-steroid dehydrogenase and steroid 5 - 4-ene-isomerase: purification from microsomes, substrate kinetics, and inhibition by product steroids. Journal of Steroid Biochemistry $\mathbf{3 1}$ 785-793. (https://doi.org/10.1016/0022-4731(88)90287-7)

Uzumcu M, Dirks KA \& Skinner MK 2002 Inhibition of platelet-derived growth factor actions in the embryonic testis influences normal cord development and morphology. Biology of Reproduction 66 745-753. (https://doi.org/10.1095/biolreprod66.3.745)

Wagner EF 2001 AP-1 - Introductory remarks. Oncogene 20 2334-2335. (https://doi.org/10.1038/sj.onc.1204416)

Wang Y, Yuan K, Li X, Su Z, Guan H, Su Y, Ge HS \& Ge RS 2016 Leukemia inhibitory factor stimulates steroidogenesis of rat immature Leydig cells via increasing the expression of steroidogenic acute regulatory protein. Growth Factors 34 166-176. (https://doi.org/ 10.1080/08977194.2016.118319)

Weissman BA, Niu E, Ge R, Sottas CM, Holmes M, Hutson JC \& Hardy MP 2005 Paracrine modulation of androgen synthesis in rat leydig cells by nitric oxide. Journal of Andrology 26 369-378. (https://doi.org/10.2164/jandrol.04178)

Ye L, Li X, Li L, Chen H \& Ge RS 2017 Insights into the Development of the Adult Leydig Cell Lineage from Stem Leydig Cells. Frontiers in Physiology 8 430. (https://doi.org/10.3389/fphys.2017.00430) 
Zhang X, Xiong L, Liu Y, Deng C \& Mao S 2013 Histopathological and estrogen effect of pentachlorophenol on the rare minnow (Gobiocypris rarus). Fish Physiology and Biochemistry 40 805-816. (https://doi.org/10.1007/s10695-013-9887-2)

Zhang YF, Yuan KM, Liang Y, Chu YH, Lian QQ, Ge YF, Zhen W, Sottas CM, Su ZJ \& Ge RS 2015 Alterations of gene profiles in Leydig-cell-regenerating adult rat testis after ethane dimethane sulfonate-treatment. Asian Journal of Andrology 17 253-260. (https://doi.org/10.4103/1008-682X.136447)

Zhou DJ, Pompon D \& Chen SA 1991 Structure-function studies of human aromatase by site-directed mutagenesis: kinetic properties of mutants Pro-308 - Phe, Tyr-361 - Phe, Tyr-361 - Leu, and Phe406 - Arg. PNAS 88 410-414. (https://doi.org/10.1073/ pnas.88.2.410)

Received in final form 19 November 2017

Accepted 24 November 2017 http://jme.endocrinology-journals.org https://doi.org/10.1530/JME-17-0222
(C) 2018 Society for Endocrinology Published by Bioscientifica Ltd. 